\title{
Multicultural Values in Indonesian Children Story
}

\author{
Abdurahman, Yenni Hayati, and Zulfadhli \\ Universitas Negeri Padang \\ Abdurahman.padang@gmail.com
}

\begin{abstract}
This paper is aimed to explain the expression of multicultural values in children's story in Indonesia. The method used in this research is the content analysis method used to interpret the literary works. This research data was taken from the literary works that are intended for children, which is written by young writer or adults who appeared in the 2000s in Indonesia. Based on the results of data analysis, it was found that children literature in Indonesia is quite rich in exploring multicultural values such as gender, religion, ethnicity, race, culture, and economy. In the children's literature, there is a learning to respect each other's differences. In the children's literature, there is a series of instructions relating to the idea of mutual respect for human differences. These differences were illustrated by sequence of events, depictions of characters, characterizations, and the languages spoken by characters and authors in the literary works.
\end{abstract}

Keywords-multicultural values, Indonesian children literature.

\section{INTRODUCTION}

Indonesia is a country with multicultural society. There are many ethnics, cultures, races and religious groups that are owned by the people of Indonesia. Friction between communities will be very easy to create if the people do not have an appreciation towards the difference. In fact, Azra (2007) calls Indonesia consist of very diverse societies and lives at different levels of culture or civilization, which contains large cultural disparities and gaps. In another perspective, some Indonesians live in pre-agrarian cultures, then others in agrarian cultures, some in industrial culture, and a few of them have entered the scientific culture. Therefore, the State is obliged to nurture the nation and its citizens. The state is also responsible for managing the diversity that exists in Indonesia; one way is through the construction of multicultural education.

In the context of Indonesia, multiculturalism serves as new glue for the integration of the Indonesian as a nation, especially in the era of reformation. Cultural uniformity is no longer relevant to the conditions and spirit of global democracy that also increases with the period of reform. Multicultural ideology is expected to be absorbed in the various interactions that exist in every structure of human life, activities (social, economic, political, etc.) which is the form of a culture.

The cultural diversity of a nation can be a major problem if the people fail to foster mutual respect for differences in culture, religion, ethnicity, race and gender. For that purpose, there should be a media that can guide the Indonesian as nation or the children of Indonesia in particular. The purpose of this media is to increase the sensitivity to respect each other's differences, because the mutual respect is able to minimize the emergence of conflict in society.

A heterogeneous society is a representation of multiculturalism. The existence of multiculturalism certainly has a positive and negative side. The positive side of multiculturalism is the courage to accept differences as an asset and energy for unity. Accepting differences not only with the competence of skills, but rather more related to perceptions and attitudes according to the reality of life as a whole. On the contrary, the negative side of multiculturalism is the emergence of rejection of others, both individuals and groups. This happens because they cannot accept the differences and the differences are considered improper or wrong. The indifference or rejection of others is essentially the coercion of uniformity and eliminates the uniqueness of the other, both individual and group.

The hierarchical social construction that firmly rejects the multicultural, establishes the recognition that a group is superior to the other as well as claiming beyond their rights by depriving the rights of others. The plurality of such local people is not only horizontal (ethnic, religious, and others), but also often vertical. This vertical tendency leads to the polarization of status and social class based on the amount of wealth or occupation in society. In the first instance, the development of the market economy makes certain groups of people, especially certain ethnic groups which have trading tradition. This situation also upgrades their social class into middle-upper class. As a result, there is social jealousy in local communities whose economies are not developed (especially in the economic field). In contrast, in the second case, certain ethnics and religious groups that originally were external of the mainstream especially in the outside, begin to enter the main current. This can lead to primordial friction, especially if it is underpinned by certain political and economic interests, In order to minimize negative events in multicultural societies such as Indonesia, the paradigm of dialogue or mutual understanding are needed to overcome the negative friction of a nation disintegration problem. A fundamental understanding of tolerance and mutual respect in this case are crucial. The communication once again plays an important role; it can also open up healthy dialogues between leaders of communities, religious 
leaders, and government as facilitators. A culture internally is a plural matter, a continuous dialogue in this case is necessary. In the midst of a multicultural society, a miscommunication will become very risky because it tends to lead to a fundamental problem. Horizontal conflicts or intercommunity conflicts often occur due to lack of positive communication. In fact, social conflict is both usual and natural in a social community. However, it becomes another story when the social conflicts that develop in society lead to destructive action.

One of the medium of learning which often describes multiculturalism is literary work. Literary works often depict differences in culture, religion, ethnicity, race, and gender that are seen through the depiction of the characters. Children "s literature is an efficient medium for teaching children about science, the values of pluralism (multicultural), moral values, ethical values, and religious values; the literary work is sustained by the structure of the story that helps the child to better understand the things contained in the science and teaching of moral value (Butzow et al., 2000).

Children"s literature is indirectly able to influence the viewpoint of readers (in this case the children) in addressing and looking at the differences, especially children 's literature that explores multicultural values. Through reading the literary works, readers (children) will learn how to appreciate the differences they encounter in everyday life.

Multiculturalism can be interpreted as an ideology that calls for recognition of respect, and mutual support between inter-ethnic, religious, group and cultural in a modern society. Multiculturalism is opposed to monoculturalism and assimilation that has become a nation/state paradigm since the 19th century. Monoculturalism requires a homogeneous unity of cultures, while assimilation is the unification of two or more cultures, reducing differences to create a new culture. Multiculturalism does not want homogeneity or reduction of differences, but multiculturalism emphasizes the diversity of cultures in harmony.

Multiculturalism is in accord with some other notions such as pluralism, open society, and globalism. Pluralism is a notion that is based on the reality of plurality in society. It does not begin with the assumption that every culture is the same, but the difference is inevitable. Pluralism is synonymous with the understanding of open society that enables the establishment of democracy and prevents the formation of authoritarianism. In an open society, one can learn from others; a group can learn from other groups. An open society contains the potential of innovation and the development of science which further encourages the change of society to a better direction and enables the development of world peace and globalization.

The main reference for the realization of a multicultural Indonesian society is multiculturalism, a view that seeks to recognize the equality of different groups both individually and culturally (Fay 1996, Jary and Jary 1991, Watson 2000). In this multiculturalism model, a society is seen as having a generally accepted culture with a mosaiclike style that includes small cultures within it. In the view of multiculturalism in Indonesia, Bhinneka Tunggal Ika is not interpreted as the diversity of tribes and cultures, but the cultural diversity that exists in Indonesia. It has been previously expressed in the explanation of article 32 of the 1945 Constitution, "Culture of the nation (Indonesia) is the tops of regional culture" (Suparlan, 2002).

Another concepts relevant to multiculturalism are matters relating to equality, politics and democracy, justice and law enforcement, employment and endeavor, human rights, cultural rights of communities and minorities, ethical and moral principles, and the level and quality of productivity. Then the issues of multiculturalism are also related to the majority-minority issue or dominant-non-dominant issue, occurring in societies that are different from religion, ethnicity, language, ethnicity, whether education, view on life, occupation, and even social status. Multiculturalism issues are found in many literary works, including children's literature.

There are three requirements of literary works as children's literature, namely (1) if the main character is children, (2) the relationship of ideas, themes, and languages are simple, and (3) also contains moral teachings (Obi et al., 2010). Another requirement of children"s literature is the story should be able to provide information about life experiences and moral teaching in life. Child literature also always contains values that affect children, something that is related to social, cultural, history, and ideology (Hunt, 1993).

\section{METHOD}

A good children es literature should be interesting. This is a major aspect of children's literature. A child stories will be interesting if the story elements are developed in a balanced way, so that each element of the structure can be complementary and well-proportioned. It is similar to what has been suggested by Huck et al. (1989) which state that a good children 's story must contain two thing; personal values and educational values. Personal values can be categorized as , good ${ }^{e e}$ in children's literature if: (1) giving pleasure to the child, (2) offering narration as a way of reasoning, (3) developing a children's imagination, (4) providing a variety of experiences, (5) developing an insight opinion towards human behavior, and (6) presenting a common (universal) experience. Children se literature contains good educational value if: (1) able to develop the language ability of children, (2) able to develop children "s storytelling skills, (3) able to develop reading skills, (4) able to support writing skills, and (5) can enrich the insights of children"s literature world (Carol Lynch-Brown and Carl M. Tomlinson, 2003). In agreement with that, Nurgiyantoro (2005) 
stated that children's literature has a great contribution to the development of the child"s personality in the process towards adulthood as a human being who has a clear identity.

To reveal how the expression of multicultural values in children "s literature, researchers exercised content analysis method (content analysis). Content analysis is applied to reveal, understand, and capture the messages of literary works. Content analysis research in the field of literature is based on the axiom that researchers want to convey a hidden message to the reader. The message is the content (meaning) that should be fabricated by the reader. This research is a strategic way to uncover and understand the literary phenomenon, especially to open the symbolic literary masks (Endraswara, 2003).

Content analysis method basically can take advantage of quantitative and qualitative data. However, in the field of literature, most of the data is obtained qualitatively. The process of content analysis in literature should meet the following requirements, (a) literary texts need to be systematically processed, using pre-designed theories, (b) the text is sought for units of analysis and then categorized according to theoretical reference, (c) the analysis process should be able to contribute to theoretical understanding,(d) analysis process based on description, and (e) the analysis is conducted qualitatively.

The source of this research data was literary works that are destined for children written by the young authors or adults. The literary works used as the source of this research data are literary works that have the following criteria. (1) Children's literature in the form of novel. (2) Works published in the 2000s. This election was due to the reason that children"s literature began to become common and more popular since the 2000s, precisely since December 2003 when the KKPK series of DAR! Publishers appeared in public. Mizan began to be published and received excellent reviews from children "s readers. (3) The genre of the works was contemporary realist fiction. The characters displayed were ordinary people along with their life problems. The setting of the story was a familiar place with the readers like schools, homes, parks, and other places close to the lives of children. Highlighted events were common events in everyday life of a child. Based on these criteria, ten pieces of children's literatures were obtained which are written by adults and children.

\section{FINDING AND DISCUSSION}

There are several values of multiculturalism explored in children's literature, including; free and equal, identity, and rejecting violence. The following descriptions will explore the multicultural values associated with the concept of free and equal in children"s literature in Indonesia.

According to KBBI (2008), ,free $e^{e e}$ is completely unimpaired ordisturbed, so that it can easily move, talk, do and every little thing. Meanwhile, ,equal ${ }^{\mathrm{ee}}$ is the same level, position and so on. Molan (2015, p. 50) explains ,free ${ }^{\mathrm{ee}}$ and ,equal'are an ethical principle that must be built in a multicultural society. The recognition of human dignity can not be separated from the recognition of freedom and equality. ,Freedom ${ }^{\text {ec }}$ in development and self-expression is assumed to be identity, while ,equality ${ }^{e e}$ is presumed in organizing life together harmoniously. Freedom is often interpreted as no rule at all, acting mindlesslyor, at will.Thus, the obedient person is then regarded as a prisonlike person. In fact, ,freedom ${ }^{\text {ee }}$ means no forces, or able to make their own decisions and doing something responsibly.

Data of ,free and equal ${ }^{\text {ee }}$ value are divided into several indicators, which are mutual understanding, a sense of solidarity, mutual help, affection towards each other, sharing among others, good acceptance for other countries to engage in economic activity, and freedom in economic affairs. Some of these indicators are reflected in the narrative of the characters, narrative of the narrator, and actions of the characters contained in children "s literature in Indonesia. Mutual understanding was seen from the attitude of characters who care about the suffering and fatigue experienced by their friend as contained in the novel Kado Untuk Putri Ungu by Syamsa Hawa. In this novel, three children were concerned about the problem of another child named Putri, who is the daughter of the school's canteen. Putries mother was sick, so she have to look after the canteen alone. The condition was exploited by other children to steal the foods and made a huge loss for Putri.This event was witnessed by three other girls. The three daughters wanted to help Putri, which is shown in the following quote.

"Is she the child of the canteen"s maid?" One of them asked to be sure.

"Yes, that's true! If I am not mistaken, her name is Putri. I did not see her mother in a few days, in fact, she is sick."

"Let's visit her mother! I know where it is. It's not too far from my house."

The three girls agreed to see Putriees mother after the schooldays.

(Hawa, 2010, p. 73).

The quotation above shows the concept of ,mutual understanding ${ }^{\text {ee }}$ which is described by the behavior of the characters depicted in the attitude of three young students who understand the suffering and difficulties experienced by the Putri.Other than visiting Putries mother, the three young characters also gave a gift for Putries birthday. Putri desperately wants to get a gift from her mother, but it is impossible right now because her mother is sick. The three children prepare presents for Putri; it is a piece of veil desired by Putri. It is seen in the following quotation. 
Putries eyes lit up as soon as she saw the contents of the box.

"Purple veil? Is this true for me, Ma? Waaah."

Time seemed to stop when the Putri grasped the beautiful purple veil, the fabric feels very soft, the color is quite good, the model looks so expensive. Putri really did not expect to receive this glorious gift. Mother's kiss and prayer is really wonderful, especially with this purple veil. Putri is very grateful (Hawa, 2010, p. 84).

In the children's literature above, the author inserts a ,mutual understanding ${ }^{\text {ee }}$ attitude expressed through the actions and dialogues of characters in the story. Supporting characters understand Putries difficulties and desires to have the veil, and it is manifested by giving a gift on Putries birthday in the form of a purple veil.

The other ,free and equal ${ }^{\text {ee }}$ values of multiculturalism found in children $\mathrm{s}$ literature is a sense of loyalty. This depiction is seen from the attitude of friends of the main character who always accompany him in realizing her dream which is depicted in Run, Zahra! Run! novel. This novel describes of a child named Zahra who will follow the run competition in her town. To win the race, Zahra requires intensive training and strict discipline. The story also provides Winda and Wanda as two loyal friends who always support Zahra. They both always accompany Zahra for practice every day. They also watch over Zahra 's time spends on running. Winda and Wanda were also present when Zahraes father was collapsed and hospitalized.It is seen in the following quotation.

Today, I will practice speedy run for the last time under Windaes supervision. I will practice using a treadmill (Anggraini, 2012, p. 35).

I feel my runnings are getting heavier even though this is not a climb. Bam! I was shocked. Everyone saw at my back. I was startled, ashamed, disappointed. My father apparently fell on the track. My father could no longer conquer this obstacle (Anggraini, 2012, p. 93).

The quotation above illustrates the solidarity of the supporting characters towards main character in the children 's story.Although Zahra failed to win the competition because her father fainted on the race, her two best friends, Winda and Wanda continued to support her, and they always accompanied Zahra who was in the midst of disappointing at her father. They also persuaded her to forgive her father. It shows the loyal attitude of the supporting characters to the main character in the children 's story. The portrait provides an understanding to the readers, especially young readers to always accompany their friends in any condition, either good or bad. These values are what the authors want to share through their literary work.

Aside from the value of ,solidarity", the value of ,mutual help ${ }^{\text {ee }}$ is also reflected in children ${ }^{\text {es }}$ literature, both written byyoung or adult authors.A sense of ,mutual help ${ }^{\text {ee }}$ is shown by the main character, illustrated through the behavior and speech of the characters. A sense of mutual help can be seen from the relationship of a character with a friend of the same age, an older person, and or someone else who needs help. The depiction shows the awareness and sensitivity of the characters towards the environment around them. It indirectly provides a learning of mutual help in social life. Some images are seen in the following quotation.

"Dimas, do you mind to go to the market? I am still cooking the chicken stuff. Besides that, you sister

Vivi will wake up in a minute," His mother confirms it again (Cendikia, 2013, p. 6).

From the above quote, a boy named Dimas is seen helping his mother to shop for daily necessities.Dimas is accustomed to helping his mother, because he knows his mother was busy working on the neighbor"s order and she also taking care of her sister.Dimas is also described as a character who is willing to help her mother"s roles in dealing with domestic issues.Dimas was never embarrassed even though he was often ridiculed by his friends. For Dimas, helping his mother is a form of devotion even though it becomes mockery by his friends. A description of ,mutual help ${ }^{\circ e}$ is also seen in the following quotation.

Nevertheless, Ninuk and I tried to help alleviate Mom's burden.We do routine works like mopping

floors, sweeping the yard, washing dishes, cleaning bathrooms, arranging our rooms, or lifting dry

clothes. That is all we can do. However, Mom is happy with that. We can not imagine Mom doing it

by herself. How piety our Mom. (Joko Susilo, 2010, p. 41).

The description in the above quotation shows the young character trying to help their mother together. The main character in the children"s story is very concerned about the difficulty of his mother in managing the household affairs. Without objection, he persuaded his brother named Ninuk to help his mother's work voluntarily.It teaches young readers to imitate the attitude of the main character who always cares for others who need help. In addition, it also teaches that we as human beings who live in society, not to be selfish and apathetic. Other exemplary attitude is also shown in the following quotation.

Oding "s grandmother is sick.Farhan is right. Odinges grandmother lived ina housecreated from zinc;

it is located near the edge of the river and nearby the garbage. She can not walk. What a pity.

There are many kites aroundthe mattres of Odinges grandmother. On a dirty and thin mattress.

"You go back there!" said Farhan to Dara.

"And do not forget to bring the medicine, ..." (Pujiastuti, 2012, p. 62). 
A young boy named Farhan, with his sister, Dara tried to help a sick old-woman by giving her a febrifuge. In addition, Farhan and Dara also helped sell kites made by Oding; the money from the sale of the kites was used to buy medicine for Odinges grandmother. It shows the attitude and value of ,mutual help ${ }^{\text {ee }}$ which is illustrated through the attitude of the character in the above children"s story.

The value of multiculturalism related to ,free and equal ${ }^{e e}$ are also illustrated by gender relation depicted in children "s literature.Although there is an unequal representation of gender relations in the children "s literature, it is used to criticize the inequality of that relatonship.It means that children "s literature still provides an understanding that equal gender relations are necessary for young readers.

According to Megawangi (1999, p.28), women and men actually have hormonal and biological differences; it creates diversity in feelings and traits. In this case, the de facto standard rejects feminist thinking that biological differences (according to de jure standard) have no implications for the nature and behavior of women and men. Based on de facto standard in any society, the concept of feminine, motherhood, and sacrifice is always identified with women, while the concept of strong, powerful and resilient are in harmony with the male image. A high-salary mother in a workplace would be willing to resign due to giving exclusive breastfeeding for her child, while there are no man would ever sacrifice his career to take care for his children at home. This is evident in the case of Shasa $\mathrm{s}$ character which would wash and iron Sam's clothes as a form of sacrifice to his brother. However, Sam is doubtful to make similar sacrifices for Shasa.

Aside from the novel Big Brother, another novel also describes the equal image between men and women shown through the depiction of father and mother figures as well as girls and boys. Even in the several novels like Mom is My Angel, Restoran untuk Mama, and Run!, Zahra Run! present female characters that are able to work together and compete with men. It is in accordance with Ibrahim "s opinion (in Ibrahim, 2005, p. 111) that at the present time, women are no longer judged on the basis of the way they bend their bodies, but women have been seen in a more positive presentation in the media, as seen from the following example; firstly, the number of women involved in the mass media is increasing, which indirectly and slowly change the perspective towards women; this perspective will also (may) affect the viewpoint of the society. Second, the number of women who produce works and achievements are increasing from year to year. This is seen from the many women who produce innovation in various fields such as art, environmental empowerment, economics, and even technology. Third, there is a tendency for cooperation between women and men not only in the form of sexual affairs, but also move forward in producing quality works. This perspective becomes the viewpoint of the authors of children 's literature in their writings. Through their writings, the authors want to show equal image between men and women and present a more positive assumption about women.

From the analysis of gender relations in children"s literature, it was found that in children s literature which is written by young authors there is a picture that prefers an equal gender relation. The narrator in this literature perceives that ideal gender relations are equal relations between men and women. The mother character (if desired), can and may make decisions like the father. Women characters do not always have to be inside the house, but they are allowed to actualize themselves outside the home. Therefore, a young character (both male and female) will have the same opportunity to show his/her talents and abilities. This is in accord with the mandate of the State contained in Presidential Decree No. 36 of 1990 which states that every child has similar right such as firstly, the right to live includes the appropriate grades of living and the health service. Second, the right to develop includes the right to get proper education, information, leisure time, arts and cultural activities, service for disabled children, their treatment and special education. Third, the right to protection, it includes a protection from all forms of exploitation, cruel treatment, ill-treatment in religious court proceedings, and; Fourth, the right to participation, including "freedom of expression and assembly, and the right to make decisions concerning themselves" (Kompas, 23th July 2008, p.38).

In contrast to children "s literature writings of young authors, adult authors in their writing described gender relations as a top-down relation. There was a clear hierarchy between male characters (fathers) as heads of families with female characters (mothers) as housewives as well as between the brothers and the sisters. The relation as mentioned above was found in every adult writeres writing which is the object of research. There were also some parts that describe the equality of men and women like when they both do housework such as cleaning the house, sweeping the yard or cooking together. However, for important decision-making, the male role remains as the head of the family and women (both mother and daughter) simply follow the decision (Hayati, 2015, p. 245-252).

The values portrayed in the children literature related to ,free and equal ${ }^{\text {ee }}$ shows that in social life it requires mutual understanding, loyal to friends, and mutual help in order to create harmony. Harmonization will foster mutual respect towards every difference that is owned by all members of the community. If mutual respect has arisen in the subconscious of every person, then the society will be able to escape from any conflicts because of that differences.

This is in agreement with the opinion of Setiadi, et al (2007, p. 149) which explains human by nature is created as a creature that carries the value of harmony.The difference that exists physically or mentally is actually God's willwhich should serve as a potential to create a life that apreciates tolerance. In this perspective, multiculturalism emphasizes cultural diversity in equality. Multiculturalism as a condition of cultural pluralism or pluralism of cultures in a society.This condition is assumed to form an attitude of tolerance (Liliweri, 2005, p. 68). 
In the life of a multicultural society, these two aspects become important. Freedom, on the one side, will allow every human being to develop and express him/herself, pursue his/her goals, and show his/her identity.Meanwhile, equality, on the other hand, will form unity and harmony in the common life through mutual respect and mutual recognition. Extreme freedom will potentially lead to chaos, whereas extreme equality has the potential to inhibit dynamics and competition for good. Freedom will be guaranteed if it performs in equality. Equality will give an opportunity for dynamics if it is exercised in freedom (Molan, 2015, p. 50).

Multiculturalism emerged as an effort to build a society that has a variety of cultures in order to live together peacefully and harmoniously. In society with diverse cultures, destructive conflicts often arise which would risk destroying the order of social life. Togetherness in this case is not meant to damage and to add problems in social life, it is to make life comfortable and harmonious.

\section{CONCLUSION}

After analyzing selected children's literature in Indonesia, researchers found the expression of the value of multiculturalism that would indirectly affect the perspective of the reader (especially children) in addressing the differences. One of the values of multiculturalism explored in the literary work of children is ,free and equale. Children "s literature in Indonesia which is the object of research illustrates that there must be mutual respect between people, both in success or in defeat. In addition, the position between men and women is equal,they together have equal rights and obligations, so there is no unfair treatment for both party. Exploring the value of multiculturalism puts literary works (especially children "s literature) can be utilized as a medium of multiculturalism learning both at school or in the family environment.

\section{References}

Anggraini, D. (2012). Run, zahra! run! Jakarta: Noura Books.

Azra, A. (2007). Identitas dan krisis budaya: membangun multukulturalisme indonesia. Jakarta: Pustaka Indonesia.

Butzow, C. M. dan J. W. Butzow. (2000). Science through children's literature: an integrative approach, Second Edition. Madison Avenue New York: Routledge.

Cendikia, D. (2013). Bintang angkasa. Surakarta:Lintang.

Endraswara, S. (2003). Metodologi penelitian sastra epistemologi, model, teori, dan aplikasi. Yoyakarta: FBS Universitas Negeri Yogyakarta.

Fay, B. (1996), Contemporary philosophy of social science: a multicultural approach. Oxford: Blackwell

Hartono., T. S. (2009). Gita dan seribu kunang-kunang. Bandung: Mizan Pustaka Utama.

Hawa, S. (2010). Kado untuk putri ungu. Jakarta: Cakrawala Publishing.

Huck, C. S., S Heple, dan J Hicman. (1989). Children's literature in the elementary school. New York: Holt Renehart and Winston.

Hunt, P. et al. (1993). Literature for children contemporary criticism. London: Routledge.

Ira. (2012). Restoran untuk mama. Bandung: Mizan.

Jary, D. dan J. Jary, (1991), “Multiculturalism” Hal.319. Dictionary of sociology. New York: Harper.

Liliweri, A. (2005). Prasangka dan konflik: komunikasi lintas budaya mayarakat multikultur. Jakarta: PT LkiS Pelangi Aksara.

Lynch-Brown, C. and C.M. Tomlinson. (2003). Essentials of children's literature. New York: St. Martin's.

Megawangi, R. (1999). Membiarkan berbeda: sudut pandang baru tentang relasi gender. Bandung: Mizan.

Molan, B. (2015). Multikulturalisme: cerdas membangun hidup bersama yang stabil dan dinamis. Jakarta: Indeks.

Nurgiyantoro, B. (2005). Sastra anak: pengantar pemahaman dunia anak. Yogyakarta: Gajahmada University Press.

Obi, C et al,. (2010). Children's literature. University of Nigeria.

Pujiastuti, Nurhayati. (2012). Kakakku tersayang. Surakarta: Lintang.

Setiadi, Elly M. dkk. (2007). Ilmu sosial dan budaya dasar. Jakarta: Kencana

Suparlan, P. (2002). "Menuju masyarakat Indonesia yang multikultural” Jurnal Antropologi Indonesia, tahun XXVI, no.69, UI dan Yayasan Obor Indonesia.

Watson, C.W., (2000), Multiculturalism. Buckingham-Philadelphia: Open University Press. 